\title{
Further evaluation of herbicides in yam (Dioscorea sp.)'
}

\author{
Li C. Liu, ${ }^{2}$ Miguel Santiago-Córdova ${ }^{y}$ and Agenol González"
}

\begin{abstract}
Two trials were carried out during 1986-87 at the Corozal substation to evaluate six herbicides for weed control in yam. In the first test, herbicides evaluated were ametryn, fluazifop-P, oxyfluorfen and paraquat. Ametryn at $4.48 \mathrm{~kg}$ ai/ha, in sequential application with fluazifop-P at $0.56 \mathrm{~kg} \mathrm{ai} / \mathrm{ha}$, was highly effective against broadleaf weeds. Oxyfluorfen alone and oxyfluorfen + paraquat were also highly effective, but both treatments caused slight to moderate crop injury. In the second trial, ametryn, fluazifop-P, paraquat, cinmethylin and metolachor were evaluated. Ametryn at $4.48 \mathrm{~kg}$ ai/ha in sequential application with fluazifop at 0.84 $\mathrm{kg}$ ai/ha again proved to be highly effective. Cinmethylin alone was poor against broadleaf weeds. Its sequential application with paraquat slightly improved weed control. Metolachor at 3.54 and $7.08 \mathrm{~L}$ hat paraquat also provided good weed control. Its sequential application with paraquat slightly improved weed control. Metolachor at 3.54 and 7.08 Wha + paraquat also provided good weed control. In the first planting there were no significant differences in tuber yield between the weeded check and other herbicide treatments except for the fluazifop-P alone treatments. In the second planting, with the exception of the cinmethylin alone treatments and one of the cinmethylin + paraquat treatments, there were no significant yield differences between the weeded check and the herbicide treatments.
\end{abstract}

\section{RESUMEN}

Evaluación adicional para herbicidas en ñame (Dioscorea sp.)

Durante 1986-87, se realizaron dos pruebas de campo en la subestación de Corozal para evaluar siete herbicidas en ñame (Dioscorea sp.). En la primera prueba se evaluaron ametryn, fluazifop-P, oxyfluorfen, $y$ paraquat. Ametryn a razón de $4.48 \mathrm{~kg}$. p.a./ha. en sucesión con el fluazifop-P a $0.56 \mathrm{~kg}$. p.a./ha. resultó altamente eficaz contra malezas de hoja ancha y gramíneas. Los tratamientos de fluazifop-p solo no reprimieron las malezas de hoja ancha. Oxyfluorfen solo y oxyfluorfen + paraquat también ejercieron un control excelente de las malezas, pero fueron de leve a moderamente tóxicos al ñame. En la segunda siembra, se evaluaron ametryn, fluazifop-P, paraquat, cinmethylin y metolachor. Ametryn a razón de $4.48 \mathrm{~kg}$. p.a./ha., en secuencia con fluazifop-P a 0.84 kg. p.a./ha. reprimió mejor las malezas de hoja ancha y las gramíneas. Cinmethylin no fue satisfactorio en la represión de las malezas de hoja ancha. Sin embargo, en cinmethylin aplicado en secuencia con paraquat mejoró la represión de ambos tipos de malezas. Metolachor aplicado en secuencia con paraquat reprimió mejor las de hoja ancha y las gramíneas.

'Manuscript submitted to the Editorial Board 16 January 1990.

${ }^{2}$ Plant Physiologist, Department of Crop Protection.

${ }^{3}$ Research Assistant, Department of Horticulture. 
En la primera prueba no hubo diferencias significativas en rendimiento entre los testigos desyerbados y los tratamientos de herbicidas, con excepción del fluazifop-P solo. En la segunda prueba, excepto con el cinmetilino aplicado solo y uno de los tratamientos de cinmetilino + paraquat, no hubo diferencias significativas entre el testigo desyerbado y los demás tratamientos herbicidas.

\section{INTRODUCTION}

Yam (Dioscorea spp.) is the most important root and tuber crop in Puerto Rico. In 1986-87, the production of yam reached 12,909 metric tons with a farm value of $\$ 5.7$ million (3). One of the most important factors limiting yam production has been the high cost of labor to control weeds. According to González Villafañe et al. (7), manual weeding amounted to $27 \%$ of total yam production cost. In Puerto Rico, farmers are increasingly depending on herbicides to reduce production costs of this crop. The status of weed control research in tropical roots and tubers was reviewed by Moody (12) in 1974. Literature pertaining to chemical control of weeds has been extensive $(1,2,4,8,9)$. In Puerto Rico, Liu et al. (10) field screened seven herbicides during 1979-80. Ametryn was the most effective as a preemergence herbicide, whereas paraquat was the least phytotoxic as a post directed spray. Consequently, both ametryn and paraquat have been registered under special local need section 24-C for yam. The use of glyphosate as either preemergence or postemergence has been studied by Liu et al. (11). Preemergence application of this compound was safer than postemergence treatment. Cortés and Beale (5) determined the critical period of weed competition in yam from planting time to the first 3 to 4 months. Herbicides are needed to maintain yam fields weed free during this critical period of development.

Several preemergence and postemergence herbicides have recently become available at the time when certain registered herbicides may be dropped by the manufacturers because of the high cost of reregistration. Efforts to evaluate these new compounds were intensified. The present study was initiated to evaluate ( \pm )-2-[[4-[[5(trifluoromethyl)2pyridinyl] oxy]phenoxy propanoic acid (fluazifop-P) and 2-chloro-1-(3ethoxy-4-nitrophenoxy)-4-trifluoromethyl)benzene (oxyfluorfen) and their mixtures with either ametryn or paraquat in one trial and exo-1methyl-4-

(1-methylethyl)-2 - [(2-methylphenyl)methoxy] -7-oxabicylo 2.2.1] heptane (cinmethylin) and 2-chloro-N-(2-ethylphenyl)-N-(2-methoxyl-1methylethyl) acetamide (metolachor) and their mixtures with paraquat, fluazifop-P alone and its mixture with ametryn in another trial in yam.

\section{MATERLALS AND METHODS}

Trial 1

The experiment was established on a Corozal clay (an Ultisol) at the 
Corozal substation. A randomized complete block design with four replications was used. The individual plot consisted of four 4.6-m rows with $1.2 \mathrm{~m}$ between rows. The planting distance between plants was $0.6 \mathrm{~m}$. Yam cultivar Guinea Negro (Dioscorea rotundata Poir) was planted 7 April 1986. All herbicides were applied as aqueous sprays either preemergence or postemergence. A knapsack sprayer fitted with 8003 Teejet tip was used. These treatments included fluazifop-P (Fusilade 2000 ) at 0.28 and $0.56 \mathrm{~kg}$ ai/ha alone or its combination with paraquat (Gramoxone). Preemergence spray of ametryn and oxyfluorfen was applied the next day after planting at a volume equivalent to $468 \mathrm{~L} / \mathrm{ha}$. Postemergence spray of fluazifop-P and paraquat was applied twice (14 May and 20 Oct. 1986) and once (18 Aug. 1986) at a spray volume equivalent to $936 \mathrm{~L} / \mathrm{ha}$. All other agronomic and pest management practices were in accordance with recommendations for root crop production in Puerto Rico (6). Weeded control plots were hand-weeded three times at approximately 6-week intervals. Weed control and phytotoxicity were rated visually at specified times. Marketable yam tubers were harvested 26 January 1987.

\section{Trial 2}

The experiment was established on the same Corozal clay at the Corozal Substation. A randomized complete block with four replications was used. The experimental plot consisted of four 4.6-m long rows with $1.2 \mathrm{~m}$ between rows. The same yam cultivar Guinea Negro was planted 2 March 1987. Preemergence ametryn (Evik), cinmethylin (Cinch), and metolachor (Dual) were applied the next day after planting. Postemergence paraquat (Gramoxone) was applied 18 May and 20 July 1987, and fluazifop-P (Fusilade 2000) was applied 21 April and 28 Sept. 1987. A knapsack sprayer was used for applying preemergence and postemergence herbicides at spray volumes of 468 and $936 \mathrm{~L} / \mathrm{ha}$, respectively. All agronomic and pest management practices were in acccordance with standard recommendation (6). Weed control and phytotoxicity ratings were made periodically. The yield data were obtained 16 Dec. 1987.

\section{RESULTS AND DISCUSSION}

\section{Trial 1}

Predominant weed species encountered in experimental plots were guinea grass (Panicum maximum Jacq.), bermuda grass [Cynodon dactylon (L) Pers.], spreading dayflower (Commelina diffusa Burm. f.), cadillo (Urena lobata L), woodsorrel (Oxalis intermedia A. Rich.), wild poinsettia (Euphorbia heterophylla L), red tasselflower (Emilia sonchifolia (L.) DC.], morning glory (Ipomoea tiliacea (Willd.) Choisy], goose grass [Eleusine indica (L.) Gaertn.], balsam apple (Momordica charantia L.) and wild bush bean [Macroptilium lathyroides (Sw.) 
TABLE 1.-Effect of different herbicide treatments on weed control, phytotoxicity and tuber yield of yam (Dioscorea rotundata) at the Corozal Substation

\begin{tabular}{|c|c|c|c|c|c|c|c|c|c|}
\hline \multirow[b]{3}{*}{ Treatment } & \multicolumn{6}{|c|}{ Weed control ratings' } & & & \multirow[b]{3}{*}{ Tuber Yield³ } \\
\hline & \multicolumn{3}{|c|}{ Broadleaf weeds } & \multicolumn{3}{|c|}{ Grasses } & \multicolumn{2}{|c|}{ Phytotoxicity² } & \\
\hline & $5-14-86$ & $6-6-86$ & $11-17-86$ & $5-14-86$ & $6-6-86$ & $11-17-86$ & $6-6-86$ & $11-17-86$ & \\
\hline & & & & & & & & & kg/ha \\
\hline \multicolumn{10}{|l|}{$\begin{array}{l}\text { 1. Ametryn } 4.48 \mathrm{~kg} \text { ai/ha } \\
\text { (pre) + fluazifop-butyl }\end{array}$} \\
\hline $0.28 \mathrm{~kg}$ ai/ha (post) & 63 & 30 & 50 & 41 & 93 & 96 & 0 & 0 & $4,587 \mathrm{abc}$ \\
\hline \multicolumn{10}{|l|}{$\begin{array}{l}\text { 2. Ametryn } 4.48 \mathrm{~kg} \text { ai/ha } \\
\text { (pre) }+ \text { fluazifop-butyl }\end{array}$} \\
\hline $0.56 \mathrm{~kg}$ ai $/ \mathrm{ha}$ (post) & 64 & 25 & 53 & 44 & 97 & 99 & 0 & 0 & $6,320 \mathrm{ab}$ \\
\hline \multicolumn{10}{|l|}{ 3. Fluazifop-butyl } \\
\hline $0.28 \mathrm{~kg}$ ai $/ \mathrm{ha}$ (post) & 18 & 0 & 16 & 13 & 91 & 95 & 0 & 0 & $2,095 \mathrm{c}$ \\
\hline \multicolumn{10}{|l|}{ 4. Fluazifop-butyl } \\
\hline $0.56 \mathrm{~kg}$ ai/ha (post) & 20 & 0 & 15 & 9 & 98 & 99 & 0 & 0 & $3,466 \mathrm{bc}$ \\
\hline \multicolumn{10}{|l|}{ 5. Oxyfluorfen $2.24 \mathrm{~kg}$} \\
\hline ai/ha (pre) & 99 & 89 & 33 & 95 & 89 & 45 & 10 & 10 & $5,198 \mathrm{abc}$ \\
\hline $\begin{array}{l}\text { 6. Oxyfluorfen } 4.48 \mathrm{~kg} \\
\text { ai/ha (pre) }\end{array}$ & 100 & 96 & 39 & 98 & 96 & 56 & 20 & 20 & $4,179 \mathrm{abc}$ \\
\hline \multicolumn{10}{|l|}{$\begin{array}{l}\text { 7. Oxyfluorfen } 2.24 \mathrm{~kg} \\
\text { ai/ha (pre) + paraquat }\end{array}$} \\
\hline \multicolumn{10}{|l|}{$\begin{array}{l}\text { 8. Oxyfluorfen } 4.48 \mathrm{~kg} \\
\text { ai/ha (pre) + paraquat }\end{array}$} \\
\hline 2.34 L/ha (post) & 100 & 95 & 66 & 96 & 94 & 75 & 20 & 20 & $4,230 \mathrm{abc}$ \\
\hline 9. Weed check & - & 94 & 89 & - & 93 & 89 & 0 & 0 & $7,288 \mathrm{a}$ \\
\hline 10. Nonweeded check & - & 0 & 0 & - & 0 & 0 & 0 & 0 & $2,243 c$ \\
\hline
\end{tabular}

'Weed control ratings are based on a scale of 0 to 100 , where $0=$ no control; $100=$ perfect control.

${ }^{2}$ Phytotoxicity evaluations are based on a scale of 0 to 100 , where $0=$ no stand reduction; $100=$ complete stand reduction.

${ }^{3}$ Means followed by the same letters do not differ significantly at the 0.05 probability level. 
Urban]. All oxyfluorfen treatments gave excellent control of grass and broadleaf weeds for two months (table 1). Ametryn provided fair grass control with slightly better control on broadleaf weeds. However, ametryn + fluazifop effectively controlled all grasses. Fluazifop alone did not control broadleaf weeds. Oxyfluorfen + paraquat provided better sustained weed control than oxyfluorfen alone. All oxyfluorfen treatments caused slight stunting of yam plants. Foliage development also seemed badly inhibited by oxyfluorfen. No visible crop injury provoked by fluazifop was noted in this test.

Yield obtained from this planting was lower than yields from commercial fields. The prolonged rain that fell during the seed piece germinating period had caused poor germination and also prevented replanting. There were no significant yield differences $(P=0.05)$ among the different herbicide treatments with the exception of the fluazifop alone treatments. The significantly lower yield with the fluazifop-P alone treatments could be attributed to failure in the control of broadleaf weeds. The highest tuber yield was obtained with the handweeded check. However, there were no significant yield differences between the weeded check and other herbicide treatments with the exception of the fluazifop alone treatments.

\section{Trial 2}

Predominant weed species present in experimental plots were guinea grass (Panicum maximum Jacq.), crabgrass (Digitaria sanguinalis L), para grass [Brachiaria purpurascens (Raddi) Henr.], jungle rice [Echinochloa colona (L) Link], goose grass [Eleusine indica (L) Gaertn.], wild bush bean [Macroptilium lathyroides (Sw) Urban], morning glory [Ipomoea tiliacea Willd.) Choisy], cadillo (Urena lobata L.), sensitive plant (Mimosa pudica L.), niruri [Phyllanthus niruri L.], wild poinsettia (Euphorbia heterophylla L.), red tasselflower[Emilia sonchifolia (L.) DC], and Mexican weed [Caperonia palustris (L.) St. Hil.]. Ametryn at $4.48 \mathrm{~kg}$ ai $/$ ha rate in sequential application with either fluazifop-P at $0.42 \mathrm{~kg}$ ai/ha or at $0.84 \mathrm{~kg}$ ai/ha provided excellent control of both broadleaf weeds and grasses. Fluazifop alone at either 0.42 or at $0.84 \mathrm{~kg}$ ai/ha was effective against gxasses only, with no control at all of any broadleaf weeds. Cinmethylin alone at either 1.72 or $3.44 \mathrm{~kg}$ ai/ha gave excellent control of grasses but was poor against broadleaf weeds. Cinmethylin at the same rate in sequential application with paraquat somewhat improved the weed control spectrum. Metolachor at either 3.54 or at $7.08 \mathrm{~L} /$ ha gave excellent control of grasses with only fair control of broadleaf weeds, especially cadillo. Cadillo was found to be a predominant weed in metolachor-treated plots. Metolachor at either rate in sequential application with paraquat at $2.34 \mathrm{~L} / \mathrm{ha}$ improved weed control as in the case of cinmethylin. Both cinmethylin and metolachor appeared 
TABLE 2.-Effect of different herbicide treatments on weed control, phytotoxicity and tuber yield of yam (Dioscorea rotundata) at the Corozal Substation

\begin{tabular}{|c|c|c|c|c|c|c|c|}
\hline \multirow[b]{2}{*}{ Treatment } & \multicolumn{3}{|c|}{ Broadleaf weed control at' } & \multicolumn{3}{|c|}{ Grass weed control at' } & \multirow[b]{2}{*}{ Tuber yield ${ }^{2}$} \\
\hline & $4-1-87$ & $5-18-87$ & $7-27-87$ & $4-1-87$ & $5-18-87$ & $7-27-87$ & \\
\hline $\begin{array}{l}\text { 1. Ametryn at } 4.48 \mathrm{~kg} \\
\text { ai/ha followed by } \\
\text { fluazifop-butyl at }\end{array}$ & & & & & & & $\mathrm{kg} / \mathrm{ha}$ \\
\hline $\begin{array}{l}0.42 \mathrm{~kg} \text { ai } / \mathrm{ha} \\
\text { 2. Ametryn at } 4.48 \mathrm{~kg} \\
\text { ai/ha followed by } \\
\text { fluazifop-butyl at }\end{array}$ & 88 & 85 & 32 & 90 & 99 & 79 & $10,977 \mathrm{abc}$ \\
\hline $\begin{array}{l}0.84 \mathrm{~kg} \text { ai/ha } \\
\text { 3. Fluazifop-butyl at }\end{array}$ & 90 & 84 & 30 & 89 & 99 & 83 & $14,898 \mathrm{ab}$ \\
\hline $\begin{array}{l}0.42 \mathrm{~kg} \text { ai/ha } \\
\text { 4. Fluazifop-butyl at }\end{array}$ & 0 & 35 & 0 & 0 & 96 & 76 & $14,841 \mathrm{ab}$ \\
\hline $\begin{array}{l}\text { 4. Fluazifop-butyl at } \\
0.84 \mathrm{~kg} \text { ai/ha }\end{array}$ & 0 & 33 & 0 & 0 & 98 & 80 & $10,659 \mathrm{abc}$ \\
\hline $\begin{array}{l}\text { 5. Cinmethylin at } \\
2.05 \mathrm{~L} / \mathrm{ha}\end{array}$ & 53 & 33 & 15 & 93 & 83 & 41 & $5,606 \mathrm{~cd}$ \\
\hline $\begin{array}{l}\text { 6. Cinmethylin at } \\
4.10 \mathrm{~L} / \mathrm{ha}\end{array}$ & 59 & 38 & 17 & 94 & 88 & 45 & $1,579 \mathrm{~d}$ \\
\hline $\begin{array}{l}\text { 7. Cinmethylin at } 2.05 \\
\text { L/ha followed by } \\
\text { paraquat at } 2.34 \mathrm{~L} / \mathrm{ha}\end{array}$ & 73 & 30 & 89 & 94 & 91 & 90 & $8.014 \mathrm{abcd}$ \\
\hline $\begin{array}{l}\text { 8. Cinmethylin at } 4.10 \\
\mathrm{~L} / \mathrm{ha} \text { followed by } \\
\text { paraquat at } 2.34 \mathrm{~L} / \mathrm{ha}\end{array}$ & 74 & 40 & 90 & 94 & 89 & 92 & $6,999 \mathrm{bcd}$ \\
\hline $\begin{array}{l}\text { 9. Metolachlor } 3.54 \mathrm{~L} / \mathrm{ha} \\
\text { followed by paraquat } \\
\text { at } 2.34 \mathrm{~L} / \mathrm{ha}\end{array}$ & 71 & 40 & 91 & 93 & 73 & 90 & $11,732 \mathrm{abc}$ \\
\hline
\end{tabular}


10. Metolachlor at 7.04

$\mathrm{L} / \mathrm{h}$ a followed by

paraquat at $2.34 \mathrm{~L}$.

11. Weeded check

12. Nonweeded check 
10. Metolachlor at 7.04

L/ha followed by

paraquat at $2.34 \mathrm{~L} / \mathrm{he}$

11. Weeded check

12. Nonweeded check

$79 \quad 58 \quad 90$

90

90

$-\quad 98$
$-\quad 0$

0

-

80

98

89

90

TWeed control ratings are based on a $0-100$ scale; $0=$ no control; $100=$ perfect control.

:Means followed by the same letters do not differ significantly at the 0.05 probability level. 
to be inferior to ametryn as preemergence herbicide because both compounds failed to control cadillo. None of the above herbicide treatments tested caused any visible crop injury, except paraquat when used as a follow-up treatment. The injury caused by paraquat was associated with spray drift, and was outgrown by the yam plants within a couple of weeks.

There were no significant yield differences between the weeded check and the herbicide treatments, with the exception of cinmethylin alone and one of cinmethylin + paraquat (table 2). Ametryn at $4.48 \mathrm{~kg}$ ai/ha + fluazifop at $0.84 \mathrm{~kg}$ ai/ha treatment yielded second only to the weeded check. It shows promise as an outstanding treatment. As a result of this study, fluazifop-P is now registered for use in yams. For an increased weed control option our farmers should take advantage of this registration by using this herbicide in sequential application with ametryn, another registered herbicide.

\section{LITERATURE CITED}

1. Anonymous, 1968. Herbicide Section Report. Univ. West Indies, Dep. Crop Sci. PANS 15: $: 1-98$.

2. - 1972. Farming Systems Program. 1972. Rep. Int. Inst. Trop. Agric. Ibadan, Nigeria.

3. - - 1987. Ingreso Agxicola de P. R. 1986-87. Depto. de Agricultura, Oficina de Estadisticas Agricolas, Santurce, P. R.

4. Attenburrow, D. C., 1965. Some herbicide screening trials on vegetables in Kenya. PANS 11: 28-37.

5. Cortés, J. A. y A. J. Beale, 1984. Efecto de la competencia de las malezas en el rendimiento final del name Habanero (Dioscorea rotundata Poir). Proc. 19th Caribbean Food Crops Soc. Meeting 19: 146-54.

6. Estación Experimental Agricola, 1976. Conjunto Tecnológico para la Producción de Cosechas Farináceas. Publ. 101, Univ. P. R., Río Piedras, P.R.

7. González-Villafañe, E., G. R. Espinet and J. L. Troche-Ducot, 1980. Análisis Económico de la Producción de Ñames de Puerto Rico, Publ. 132, Esta. Exp. Agric. Univ. P. R.

8. Kasasian, L., 1971. Weed control in the Tropics, Leonard Hill, London.

9. - and J. Seeyave, 1967. Weed control in root crops grown in the West Indies. Proc. Int. Symp. Trop. Root Crops, Trinidad, Vol. 2. Section 4, Crop Protection 20-25. Trinidad, West Indies.

10. Liu, L. C., J. J. Green-Ortiz and E. Acevedo-Borrero, 1981. Herbicide screening trials on yams (Dioscorea spp.) J. Agric. Univ. P. R. 65 (4): 353-60.

11. - - M. A. Santiago-Córdova, E. Acevedo-Borrero and R. Montalvo-Zapata, 1981. Glyphosate for weed control in two tropical root crops. Proc. 17th Caribbean Food Crops Soc. Meeting 17: 174-87.

12. Moody, K. and H. C. Ezumah, 1974. Weed control in major tropical root and tuber crops-A review. PANs 20: 292-94. 